PUBLIPRENEUR POLIMEDIA: JURNAL ILMIAH
JURUSAN PENERBITAN POLITEKNIK NEGERI MEDIA KREATIF

Vol. 8, No. 1, July 2020

Submitted: 5 July 2020

Revised: 15 July 2020

Accepted: 30 July 2020

\title{
FACTORS THAT INFLUENCE STUDENT SATISFACTION IN USINGE-LEARNING MEDIA DURING THE CORONA PANDEMICPERIOD
}

\author{
Mohammad Rizal Gaffar ${ }^{*}$, Chandra Budhi Septyandi ${ }^{2}$. \\ 1,2Politeknik Negeri Bandung \\ E-mail: mohammad.rizal@polban.ac.id ${ }^{1}$, chandra.budhi@polban.ac.id ${ }^{2}$
}

\begin{abstract}
ABSTRACT The Corona pandemic has spread almost everywhere in the world. Indonesia became one of the affected countries. The education sector became one of the affected sectors and changed the learning process, which was initially dominated by conventional learning into E-Learning based learning. This sudden change makes all components of learning, especially teachers and instructors, have to adapt to use the facilities available. However, this sudden change inevitably creates obstacles to the achievement of learning objectives. Therefore, it is considered important to evaluate the learning process through this e-learning facility so that teaching participants can feel satisfied and the learning objectives are achieved. The research method used is a mixed method method by conducting a qualitative method first to design a model of insight obtained from interviews with respondents then using quantitative methods to obtain statistical values to strengthen the proposed model.A total of 153 respondents' data were processed using Partial Least Square software. The results of data processing prove model is valid and reliable. The model has strong predictive power. From four proposed variables, Perception Ease of Use, Perception Usefulness, and Facilitating Condition have a significant positive effect on User Satisfaction (students). And student satisfaction has a significant positive effect on the future use of e-learning media behavior.
\end{abstract}

Keyword:E-learning, Satisfaction, Corona pandemic

\section{FAKTOR YANG MEMENGARUHI KEPUASAN MAHASISWA DALAM MENGGUNAKAN MEDIA E-LEARNING SELAMA PERIODE PANDEMIK CORONA}

\begin{abstract}
ABSTRAK
Pandemi Corona sudah mewabah hampir di seluruh belahan dunia. Indonesia menjadi salah satu negara terdampak. Sektor pendidikan menjadi salah satu sektor yang terdampak dan merubah proses pembelajaran yang awalnya mayoritas didominasi pembelajaran konvensional menjadi pembelajaran berbasis E-Learning. Perubahan yang bisa dikatakan mendadak ini membuat seluruh komponen pembelajaran, terutama pengajar dan peserta ajar harus beradaptasi menggunakan fasilitas yang tersedia. Namun, perubahan yang sangat mendadak ini pasti menimbulkan hambatan atas tercapainya tujuan pembelajaran. Oleh karena itu, dirasa penting untuk mengevaluasi proses pembelajaran lewat fasilitas e-learning ini sehingga peserta ajar bisa merasa puas dan tujuan pembelajaran tercapai. Metode penelitian yang digunakan adalah metode mixed method dengan melakukan metode kualitatif terlebih dahulu untuk merancang model dari insight yang didapat hasil wawancara dengan responden lalu menggunakan metode kuantitatif untuk mendapat nilai statistik untuk memperkuat model yang telah diusulkan. Sejumlah 153 data responden diolah menggunakan softwarePartial Least Square. Hasil pengolahan data membutktikan model valid dan reliabel. Lebih lanjut Model termasuk model dengan kekuatan prediksi kuat. Dari empat variabel yang diusulkan, Persepsi Kemudahan Penggunaan, Persepsi Kegunaan, dan Kondisi Fasilitas
\end{abstract}


Pendukung yang berpengaruh positif signifikan terhadap Kepuasan Pengguna (mahasiswa). Dan kepuasan mahasiswa berpengaruh positif signifikan terhadao Penggunaan Media E-Learning di masa yang akan datang.

Kata kunci: E-learning, Kepuasan, Pandemi Corona

\section{PENDAHULUAN}

Indonesia telah menjadi salah satu negara yang terpapar dan terdampak dari merebaknya virus corona. Salah satu sektor yang terdampak dengan merebaknya pandemi virus corona adalah dunia pendidikan. Kebijakan untuk belajar dari rumah pun diputuskan pemerintah dan berlaku sejak 16 Maret 2020 (Dimas, 2020). Kebijakan ini ditempuh demi mengurangi mobilitas pelajar dan mahasiswa sehingga dapat menekan penyebaran corona (Dimas, 2020).

Proses pembelajaran jarak jauh ditempuh melalui berbagai cara. Beberapa pilihan proses pembelajaran jarak jauh adalah menggunakan aplikasi ruangguru, zoom, aplikasi pesan instan, google drive, google classroom, email, aplikasi elearning milik masing-masing institusi, dan aplikasi lainnya. Namun, tak sedikit orang tua dan siswa yang kerepotan dengan kegiatan ini(Dimas, 2020). Beberapa mahasiswa juga mengeluhkan kondisi jaringan internet yang tidak mendukung terciptanya proses pembelajaran. $\mathrm{Hal}$ tersebut bisa menghambat tercapainya kesuksesan pembelajaran (pembelajaran via e-learning).

Secara umum, kepuasan pengguna (user satisfaction) berkaitan dengan kesuksesan sistem berbasis komputer (Ives et al., 1983). Dengan kata lain, sebuah sistem berbasis komputer (e-learning) dapat dikatakan sukses bila pengguna merasa puas.

Beberapa penelitian telah dilakukan untuk menganalisis perihal kepuasan pengguna e-learning (Al-hawari \& Mouakket, 2010)(Yengin et al., 2011)(Fleming et al., 2017)(Chopra et al., 2019). Penelitian dilakukan Mouakket untuk menganalisis pengaruh Perceived Usefulness dan Perceived Ease of Use (2 faktor dari Technology Adoption Model) serta Design Feture dan Enjoyment terhadap Electronic Satisfaction dan Electronic Retention (Al-hawari \& Mouakket, 2010). Penelitian yang menganalisis pengaruh E-Learning System yang direpresentasikan oleh System Quality, Information Quality, dan Service Quality terhadap E-Learning Effectiveness yang direpresentasikan oleh Net Benefits dan User Satisfaction juga telah dilakukan (Chopra et al., 2019). Model tersebut merupakan pengembangan dari model yang dikembangkan oleh Yengin pada tahun 2011 (Yengin et al., 2011). Sementara Fleming pada tahun 2017 meneliti pengaruh Overall Satisfaction terhadap Future Use (Fleming et al., 2017).

Tentu saja model tersebut tidak bisa secara utuh diadopsi untuk mengukur kepuasan pengguna di Indonesia karena pasti terdapat perbedaan baik internal (tingkat penggunaan teknologi) maupun eksternal (infratruktur pendukung). Oleh karena itu, dilakukan penelitian awal dengan melakukan wawancara individu dengan beberapa orang sampai penulis mendapatkan insight untuk memodifikasi model. Hasil wawancara dengan lima orang mahasiswa perguruan tinggi di Bandung menghasilkan faktor yang dianggap sangat berpengaruh terhadap kepuasan penggunaan aplikasi E-learning, yaitu kemudahan menggunakan elearning, kegunaan dari penggunaan elearning, fleksibilitas, koneksi jaringan internet.

Oleh karena itu keempat faktor tersebut akan dimasukan ke dalam model usulan yang akan diteliti lebih lanjut menggunakan metode kuantitatif pada penelitian ini. Adapun luaran yang dari penelitian ini adalah sebuah model yang dapat merepresentasikan faktor-faktor 
yang mempengaruhi kepuasan dari pengguna aplikasi e-learning, dalam kasus ini adalah mahasiswa salah satu perguruan tinggi Bandung. Urgensi dari penelitian ini adalah untuk memastikan tercapainya tujuan pembelajaran yang sangat dipengaruhi oleh kepuasan mahasiswa dalam menggunakan fasilitas E-Learning.

\section{"Electronic Learning"}

"Electronic Learning" (E-Learning) didefinisikan sebagai penggunaan teknologi informasi untuk belajar, mengajar, atau memperoleh pengetahuan kapanpun dan dimanapun sehingga memungkinkan penyampaian metode dan materi pembelajaran secara "online" (Turban, Efraim; King, David; Lee, Jae Kyu; Liang, Tiang-Peng; Turban, 2015). "Elearning" sebenarnya juga termasuk pembelajaran "mobile" di mana materi pembelajaran dikirimkan ke perangkat nirkabel seperti perangkat telepon pintar, tablet atau perangkat "mobile" lainnya dan tidak hanya identik terhadap pembelajaran berbasis web (Turban, Efraim; King, David; Lee, Jae Kyu; Liang, Tiang-Peng; Turban, 2015). Sebenarnya proses pembelajaran bisa berbasis online, offline, dan gabungan dari keduanya. Hal tersebut tergantung menyesuaikan kebutuhan dari komponen sistem belajar itu sendiri. Pelatihan berbasis komputer, instruksi berbasis komputer, pendidikan online, danjenis pembelajaran lainnya dapat dikategorikan ke dalam E-Learning (Turban, Efraim; King, David; Lee, Jae Kyu; Liang, TiangPeng; Turban, 2015). E-Learning sangat berguna untuk memfasilitasi pembelajaran pada institusi pendidikan dan sangat berguna untuk menyediakan lingkungan pembelajaran yang kondusif sehingga pelatihan korporasi dapat dilaksanakan secara efektif dan efisien. E-learning juga memungkinkan pelajar belajar dari rumah (Garrison, 2011). Selain itu, penggunaan ELearning membuat pekerja dapat belajar dan memperbaharui pengetahuan dan keahlian dari tempat kerja mereka (Garrison, 2011).

Pengembangan model untuk menganalisis kepuasan penggunaan ELearning ini sudah dilakukan beberapa peneliti. Mouakket pada tahun 2010 menganalisis pengaruh faktor pada Technology Adoption Model, yaitu Perceived Ease of Use dan Perceived Usefulness ditambah dua faktor eksternal, yaitu Design Feature dan Enjoyment terhadap Kepuasan Pengguna dan Keinginan untuk menggunakan kembali aplikasi E-Learning (Al-hawari \& Mouakket, 2010). Penelitian untuk mengukur secara spesifik pengaruh usia terhadap terhadap Kepuasan Pengguna dan Keinginan untuk Menggunakan kembali di masa yang akan datang diteliti oleh Fleming pada tahun 2017 (Fleming et al., 2017). Model yang ditemukan Yengin pada tahun 2011 juga dikembangkan oleh Chopra pada tahun 2019 dengan menganalisis pengaruh System Quality, Information Quality, dan Service Quality terhadap Net Benefits dan User Satisfaction (Yengin et al., 2011), (Chopra et al., 2019). Pada dasarnya item-item pada System Quality, Information Quality, dan Service Quality telah merepresentasikan Perceived Usefulness dan Perceived Ease of Use, 2 faktor dari Technology Adoption Model.

Lebih lanjut dalam penelitian ini akan difokuskan untuk menganalisis 6 variabel hasil dari wawancara awal terhadap 5 responden mahasiswa pada salah satu perguruan tinggi di Bandung. Enam variabel tersebut adalah Persepsi Kemudahan Penggunaan (Perceived Ease of Use) aplikasi E-Learning, Persepsi Kegunaan yang diterima (Perceived Usefulness), Fleksibilitas (Flexibility), koneksi jaringan internet, Kepuasan Pengguna (User Satisfaction), dan Perilaku Penggunaan di Masa yang Akan Datang (Future Use Behavior).

Perceived Ease of Use diartikan oleh Davis pada tahun 1989 sebagai tingkat 
di mana seseorang mempercayai bahwa tidak diperlukan usaha berlebih saat menggunakan sebuah sistem (Davis, 1989). Sementara Davis mendefinisikan Perceived Usefulness sebagai seberapa besar kepercayaan seseorang terhadap peningkatan kinerjanya ketika menggunakan sebuah sistem tertentu (Davis, 1989). Kedua variabel tersebut merupakan variabel yang terdapat dalam Technology Acceptane Model yang dianalisis dan dikembangkan oleh Davis pada tahun 1989 (Davis, 1989).

Loh et. al. pada tahun 2016 menganalisis persepsi terhadap penggunaan E-Learning di Australia (Loh et al., 2016). Fokusnya adalah menganalisis pertanyaan "apa yang konsumen (murid) saya pikirkan sekarang?" (Loh et al., 2016). Hal tersebut dianggap menentukan efektivitas dari penggunaan E-Learning (Loh et al., 2016). Persepsi dari Fleksibilitas menjadi salah satu aspek positif terhadap E-Learning (Loh et al., 2016). Lebih lanjut, Fleksibilitas menjadi faktor yang paling dominan pada aspek positif pengalaman menggunakan E-Learning (Loh et al., 2016). Penilaian tinggi dari murid perihal fleksibilitas adalah karena mereka dapat kesempatan untuk belajar mandiri dan juga bisa belajar di mana saja dan kapan saja (Loh et al., 2016).

Variabel terakhir adalah perihal koneksi jaringan internet yang dianggap mahasiswa berpengaruh penting terhadap kepuasan menggunakan E-Learning. Dalam penelitian Samsudeen tahun 2019 menemukan Facilitating Condition berpengaruh positif signifikan terhadap Perilaku Penggunaan aplikasi E-Learning (Samsudeen \& Mohamed, 2019). Facilitating Condition dapat diartikan sebagai faktor lingkungan yang meyakinkan seseorang untuk melakukan beberapa kegiatan (Salloum et al., 2019). Ketika dilihat dari item kuesioner Facilitating Condition, dinyatakan perihal pentingnya keandalan dan keterbaruan teknologi, termasuk koneksi internet dalam penggunaan E-Learning (Salloum et al., 2019). Oleh karena itu, variabel keempat ini dapat dipadankan menjadi Facilitating Condition sesuai artikel Samsudeen (Salloum et al., 2019).

Keempat variabel tersebut akan dijadikan variabel independen yang dihipotesiskan berpengaruh positif signifikan terhadap User Satisfaction dan Future Use Behavior. Beberapa indikator variabel User Satisfaction dalam hal penggunaan E-Learning adalah sebagai berikut : keberlanjutan penggunaan aplikasi E-Learning dan Rekomendasi penggunaan aplikasi E-Learning kepada orang lain (Chopra et al., 2019). Dalam bidang pemasaran sendiri, secara umum User Satisfaction diartikan sebagai perasaan atau penilaian pelanggan terhadap produk atau layanan setelah digunakan (Jamal, A; Naser, 2003). Future Use behavior dalam penelitian ini diartikan sebagai perilaku penggunaan berulang aplikasi E-Learning di masa yang akan datang oleh mahasiswa.

\section{METODE PENELITIAN}

Penelitian ini bertujuan untuk eksplorasi faktor-faktor yang mempengaruhi konsumen pengguna aplikasi E-Learning. Penelitian ini akan menggunakan metode Mixed Method, kualitatif dan kuantitatif. Responden yang diambil berasal dari pengguna E-Learning pada mahasiswa di Bandung. Mix method merupakan metode gabungan dalam melakukan penelitian antara metode kuantitatif dan kualitatif(Golicic, Susan L.; Davis, 2012). Pada penelitian ini digunakan metode Mix method dengan tipe Development. Metode ini bekerjadengan cara memberi bobot sama antara dua metode (kuantitatif dan kualitatif) dan kedua metode dilakukan secara berurutan (Davis, Donna F.; Golicic, Susan L.; Boerstler, 2011). Metode kedua yang digunakan bertujuan untuk pengembangan dari temuan metode pertama (Davis, Donna F.; Golicic, Susan L.; Boerstler, 2011). 
Penelitian awal menggunakan metode kualitatif untuk mendapatkan model yang paling sesuai dengan karakteristik pengguna Indonesia. Menurut Zikmund et al. dan Cooper dan Schindler, penelitian kualitatif memiliki fokus pada pemerolehan makna yang sesungguhnya dan mendapatkan masukan (insights) tentang masalah dan pertanyaan penelitian (Indrawati, 2015). Hasil dari penelitian kualitatif awal akan menjadi dasar metode selanjutnya, yaitu metode kuantitatif.

Pada fase kuantitatif digunakan alat ukur berupa kuesioner untuk memperoleh data setiap variabel yang terdapat pada model penelitian. Pertanyaan di dalam kuesioner berjenis pertanyaan tertutup dengan tingkat pengukuran skala likert. Pertanyaan-pertanyaan untuk setiap variabel berasal dari item-item yang sudah divalidasi dari penelitian-penelitian yang sudah dilakukan sebelumnya. Variabel dalam model ini diambil berdasarkan tinjauan pustaka pada penelitian jurnal. Item-item untuk mengukur variabel diambil dari artikel Mouakket, Samsudeen, dan Loh (Al-hawari \& Mouakket, 2010), (Loh et al., 2016), (Samsudeen \& Mohamed, 2019).

Skala pengukuran yang digunakan dalam penelitian ini adalah skala Likert. Menurut Sekaran dan Bougie, skala likert merupakan skala yang didesain untuk menelaah seberapa kuat subjek setuju atau tidak setuju (Sekaran, U.; Bougie, 2009). Dalam penelitian ini digunakan five likert scale, di mana skala yang digunakan untuk member ranking ada lima tingkat.

Model penelitian akan disusun berdasarkan penyesuaian hasil wawancara awal terhadap tinjauan pustaka. Model penelitian yang diusulkan dapat dilihat dalam gambar berikut.

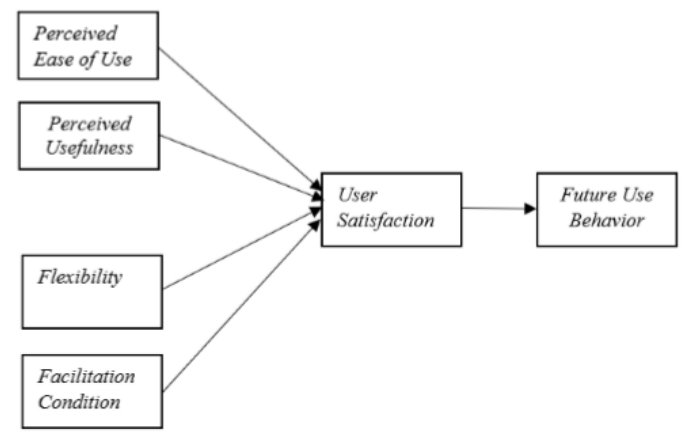

Gambar 1 Model Usulan Penelitian

Populasi yang dipilih dalam penelitian ini adalah seluruh mahasiswa yang menggunakan aplikasi E-Learning di Bandung. Dalam penelitian ini digunakan 200 sampel yang diambil dari para pengguna layanan mobile payment yang masih aktif. Bryne merekomendasikan sampel minimal yang dapat diterima untuk estimasi Structural Equation Model (SEM) adalah 100(Latan, 2012). Penelitian ini menggunakan teknik purposive sampling. Purposive sampling memilih anggota sampeltertentu yang disengaja oleh peneliti, karena hanya mereka saja yang dapat mewakili atau dapat memberikan informasi untuk menjawab masalah penelitian.

Data pada penelitian ini terdiri dari data primer dan data sekunder. Data primer berupa hasil penyebaran kuesioner kepada responden yang dipilih oleh penulis. Penyebaran kuesioner menggunakan google form dan disebar melalui internet. Sementara data sekunder berupa hasil tinjauan pustaka yang dijadikan dasar untuk melakukan penelitian ini.

\section{HASIL DAN PEMBAHASAN}

Data hasil pengisian kuesioner dari 153 responden diolah menggunakan perangkat lunak Partial Least Squareatau dapat disingkat PLS. Hasil pengolahan data menunjukan model valid dan reliabel. Hal tersebut dapat dilihat dari nilai Loading Factor (LF) setiap item lebih besar dari 0,5 
(Latan, 2012) dan nilai average variance extracted (AVE) lebih besar dari 0,5 (Liang \& Yeh, 2011). Model ini juga dikategorikan model reliabel karena memiliki nilai Composite Reliability (CR) lebih besar dari 0,7 (Zhou, 2013) dan Cronbach's Alpha (CA) lebih besar dari 0,6 (Choe \& Schumacher, 2015). Hasil lengkap pengolahan data berkenaan validitas dan reliabilitas model dapat dilihat pada tabel berikut.

Tabel 1 Hasil Pengolahan Data Uji Validitas dan Reliabilitas

\begin{tabular}{|c|c|c|c|c|c|}
\hline Var. & Item & LF & AVE & CR & CA \\
\hline PeoU & PEoU1 & 0.850 & & & \\
& PEoU2 & 0.836 & 0.645 & 0.844 & 0.725 \\
& PEoU3 & 0.717 & & & \\
\hline PU & PU1 & 0.804 & & & \\
& PU2 & 0.860 & 0.630 & 0.835 & 0.703 \\
& PU3 & 0.710 & & & \\
\hline FLEX & FLEX1 & 0.772 & & & \\
& FLEX2 & 0.864 & 0.693 & 0.871 & 0.778 \\
& FLEX3 & 0.858 & & & \\
\hline FC & FC1 & 0.810 & 0.754 & 0.859 & 0.687 \\
& FC2 & 0.923 & & 0.826 \\
\hline US & US1 & 0.923 & 0.852 & 0.920 & 0.20 \\
& US2 & 0.923 & & \\
\hline FUB & FUB1 & 0.816 & & 0.921 & 0.870 \\
& FUB2 & 0.915 & 0.796 & 0.921 \\
& FUB3 & 0.940 & & & \\
\hline
\end{tabular}

Lebih lanjut model dapat memprediksi Kepuasan Pengguna (User Satisfaction) dengan $\mathrm{R}^{2}=0,601$ dan memprediksi Penggunaan di Masa yang akan datang (Future Use Behavior) dengan $\mathrm{R}^{2}=0,745$.

Penelitian ini juga membuktikan Perceived Ease of Use $(\mathrm{t}$ statistik $=2,824)$, Perceived Usefulness( $\mathrm{t}$ statistik $=7,643)$, Facilitating Condition(t statistik $=2,767$ ) berpengaruh positif signifikan terhadap User Satisfaction. Dan User Satisfaction( $\mathrm{t}$ statistik $=43,264)$ memiliki pengaruh positif signifikan terhadap Future Use Behavior. Namun, Flexibility $(\mathrm{t}$ statistik = 1,111) terbukti tidak memiliki pengaruh yang signifikan terhadap User Satisfaction.

\section{KESIMPULAN}

Model memiliki kemampuan prediksi terhadap Perilaku Penggunaan E-learning di masa yang akan datang datang kuat dengan nilai $R^{2}=0,745$. Faktor yang mempengaruhi Kepuasan Pengguna adalah Persepsi Kemudahan Penggunaan, Persepsi Kegunaan, dan Kondisi Fasilitas Pendukung. Dan Kepuasan Pengguna mempengaruhi perilaku pengguna ke depan. Semakin Pengguna E-Learning Puas, maka Pengguna akan cenderung untuk memilih menggunakan E-Learning sebagai media pembelajran di masa yang akan datang.

\section{DAFTAR PUSTAKA}

Al-hawari, M. A., \& Mouakket, S. (2010). The influence of technology acceptance model (TAM) factors on students' e-satisfaction and e-retention within the context of UAE e-learning. Education, Business and Society: Contemporary Middle Eastern Issues, 3(4), 299-314. https://doi.org/10.1108/17537981011 089596

Choe, P., \& Schumacher, D. (2015). Influence of Different Types of Vibrations on Technical Acceptance of a Mobile Game Aiming for Hedonic Satisfaction. International Journal of Human-Computer Interaction, 31(1), 3343.

https://doi.org/10.1080/10447318.20 14.959101

Chopra, G., Madan, P., Jaisingh, P., \& Bhaskar, P. (2019). Effectiveness of elearning portal from students' perspective: A structural equation model (SEM) approach. Interactive Technology and Smart Education, 16(2), 94-116.

https://doi.org/10.1108/ITSE-052018-0027

Davis, Donna F.; Golicic, Susan L.; Boerstler, C. N. (2011). Benefits and challenges of conducting multiple methods research in marketing. 
Journal of the Academy of Marketing Science, 467-479.

Davis, F. D. (1989). Perceived usefulness, perceived ease of use, and user acceptance of information technology. MIS Quarterly: Management Information Systems, 13(3), 319-339. https://doi.org/10.2307/249008

Dimas, C. (2020). No Title. Kompas TV Web Site.

https://www.kompas.tv/article/7460 8/sorotan-dampak-corona-ke-duniapendidikan

Fleming, J., Becker, K., \& Newton, C. (2017). Factors for successful elearning: does age matter? Education and Training, 59(1), 76-89. https://doi.org/10.1108/ET-07-20150057

Garrison, D. R. (2011). E-Learning in the 21st Century: A Framework for Research and Practice. Routledge.

Golicic, Susan L.; Davis, D. F. (2012). Implementing mixed methods research in supply chain management. International Journal of Physical Distribution \& Logistics Management, 726-741.

Indrawati. (2015). Metode Penelitian Manajemen dan Bisnis. Refika Aditama.

Ives, B., Olson, M. H., \& Baroudi, J. J. (1983). The measurement of user information satisfaction. Communications of the ACM, 26(10), 785-793.

https://doi.org/10.1145/358413.3584 30

Jamal, A; Naser, K. (2003). Factors influencing customer satisfaction in the retail banking sector in Pakistan. International Journal of Commerce $\mathcal{E}$ Management, 13(2), 29-53.

Latan, H. (2012). Structural Equation Modeling: Konsep dan Aplikasi. Alfabeta.

Liang, T. P., \& Yeh, Y. H. (2011). Effect of use contexts on the continuous use of mobile services: The case of mobile games. Personal and Ubiquitous
Computing, 15(2), 187-196. https://doi.org/10.1007/s00779-0100300-1

Loh, C., Wong, D. H., Quazi, A., \& Kingshott, R. P. (2016). Re-examining students' perception of e-learning: an Australian perspective. International Journal of Educational Management, 30(1), 129-139. https:/ / doi.org/10.1108/IJEM-082014-0114

Salloum, S. A., Al-Emran, M., Shaalan, K., \& Tarhini, A. (2019). Factors affecting the E-learning acceptance: A case study from UAE. Education and Information Technologies, 24(1), 509530. https://doi.org/10.1007/s10639018-9786-3

Samsudeen, S. N., \& Mohamed, R. (2019). University students' intention to use e-learning systems: A study of higher educational institutions in Sri Lanka. Interactive Technology and Smart Education, 16(3), 219-238. https://doi.org/10.1108/ITSE-112018-0092

Sekaran, U.; Bougie, R. (2009). Research Methods for Business: A Skill-Building Approach. 5th. John Wiley and Sons Inc.

Turban, Efraim; King, David; Lee, Jae Kyu; Liang, Tiang-Peng; Turban, D. C. (2015). Electronic Commerce: A Managerial and Social Networks Perspective. Springer.

Yengin, I., Karahoca, A., \& Karahoca, D. (2011). E-learning success model for instructors' satisfactions in perspective of interaction and usability outcomes. Procedia Computer Science, 3(October 2015), 1396-1403. https://doi.org/10.1016/j.procs.2011. 01.021

Zhou, T. (2013). Understanding the effect of flow on user adoption of mobile games. Personal and Ubiquitous Computing, 17(4), 741-748. https://doi.org/10.1007/s00779-0120613-3 